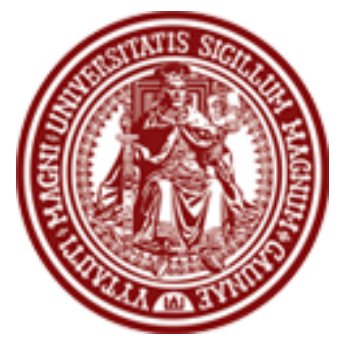

BALTIC JOURNAL OF LAW \& POLITICS

VOLUME 7, NUMBER 1 (2014)

ISSN 2029-0454

http://www.degruyter.com/view/j/bjlp

Cit.: Baltic Journal of Law \& Politics 7:1 (2014): 12-28

DOI: $10.2478 / \mathrm{bjlp}-2014-0002$

\title{
THE FREEDOM OF EXPRESSION OF MEMBERS OF THE ARMED FORCES UNDER THE EUROPEAN CONVENTION ON HUMAN RIGHTS IN JOKŠAS V. LITHUANIA
}

\author{
Stefan Kirchner \\ Associate Professor for Fundamental and Human Rights \\ University of Lapland, Faculty of Law (Finland) \\ Contact information \\ Address: P. O. Box 122, 96101 Rovaniemi, Finland \\ Phone: +358404844001 \\ E-mail address: stefan.kirchner@ulapland.fi
}

\author{
Vanessa Maria Frese \\ Law Student \\ University of Fribourg, Faculty of Law (Switzerland) \\ Contact information \\ Address: Av. de I'Europe 20, 1700 Fribourg, Switzerland \\ Phone: +41794248975 \\ E-mail address: vanessamaria.frese@unifr.ch
}

Received: January 3, 2014; reviews: 2; accepted: May 6, 2014.

\section{ABSTRACT}

Freedom of expression is one of the most fundamental rights in a democratic society. In fact, the freedom to express one's opinion and to impart, as well as to receive, information, is essential for the participation in the democratic process. The ability to make decisions as a citizen requires access to information; the participation in the life of the society requires the ability to express one's opinions. It is imperative that in a democratic society, as it is envisaged by the European Convention on Human Rights (ECHR), everybody is able to express their views, regardless as to whether these views correspond to the views of those who are in power. This ability is one of the key differences between democracy and 
dictatorship. In particular in the nation-states of Eastern Europe, which have only known freedom for a bit less than a quarter of a century, the growth of democratic structures is inextricably linked to the ability to exercise this right. But while human rights in principle pit the citizen against the State, the citizen who serves the State in a professional function might also wish to express opinions that go against the view of those who are entrusted with leading the State. This is particularly the case when it comes to members of the armed forces. The jurisprudence of the Convention organs with regard to the right of public officials and other State agents to express their opinion freely is not as coherent as it is with regard to other questions concerning the ECHR. In a case decided in late 2013, the European Court of Human Rights dealt with this question with regard to Lithuania. In this article, the authors look at the question of how far the State can restrict the freedom of expression of members of the armed forces under the European Convention on Human Rights.

\section{KEYWORDS}

European Convention on Human Rights, freedom of expression, government, military, subordination, public servant 


\section{INTRODUCTION}

The freedom of expression is not only a core right $^{1}$ within the European Convention on Human Rights ${ }^{2}$ but is also of fundamental importance for a democratic ${ }^{3}$ society; ${ }^{4}$ it forms a fundament for other rights such as the right to assembly or the right to association ${ }^{5}$. Often cases concerning the freedom of expression "raise nice defined issues of principle for practitioner, politician, academic, civil rights activist alike ${ }^{\prime \prime}$. But this does not necessarily result in clear or coherent case law. One area in which such clear lines appear to be lacking in particular is with regard to expressions made by public officials. ${ }^{7}$

The question may be raised in how far public officials and other employees of the State, including judges, elected holders of a public office and members of the armed forces, can rely on Article 10 ECHR in order to express an opinion the expression of which the State seeks to limit.

In this article, we will investigate the limits imposed in particular on members of the armed forces during their time of service. Soldiers and officers represent the State in a very specific way, as they are not elected officials but subject to command and control by those who represent the people. However, the situation of the members of the armed forces cannot easily be compared to that of public officials who often engage with citizens in a much more direct manner. While members of the armed forces are more than merely executors of military orders and of the political will of the civilian leadership, there is a general expectation on the part of the civilian public that members of the armed forces exhibit a particular loyalty to the democratically legitimized representatives of the State. In particular the experiences of World War II but also the experiences of the states which are parties to the ECHR with military coups in the decades after World War II are a reminder of the need for civilian control over the armed forces. Civilian control, though, is not the same as absolute loyalty of the members of the armed forces to the civilian leadership. Rather, the general expectation goes towards a loyalty of

\footnotetext{
${ }^{1}$ On the freedom of expression see in particular the liber amicorum for the former President of the European Court of Human Rights: Josep Casadevall, Egbert Myjer, Michael O'Boyle, and Anna Austin, Freedom of Expression: Essays in Honor of Nicolas Bratza, President of the European Court of Human Rights, $1^{\text {st }}$ ed. (Strasbourg, Council of Europe, 2012).

2 Hereinafter: ECHR. European Treaty Series No. 5

3 On the relationship between democracy and freedoms see David Beetham, "Freedom as the Foundation," Journal of Democracy 15 (2004): 61-75; Christoph Menke and Arnd Pollmann, Philosophie der Menschenrechte - zur Einführung, $1^{\text {st }}$ ed. (Hamburg: Junius Verlag, 2007), p. 170 et seq.

${ }^{4}$ Karen Reid, A Practitioner's Guide to the European Convention on Human Rights, $3^{\text {rd }}$ ed. (London: Thomson \& Sweet \& Maxwell, 2007), p. 342.

5 Ana Maria Guerra Martins, Direito Internacional dos Direitos Humanos, $1^{\text {st }}$ ed. (Coimbra: Almedina, 2013), p. 244.

${ }^{6}$ Karen Reid, supra note 4, p. 343.

7 Christoph Grabenwarter, Europäische Menschenrechtskonvention, $3^{\text {rd }}$ ed. (Munich: C.H. Beck, 2008), p. 259 et seq.
} 
those who hold a public office towards the State, its constitution and institutions. This is even more the case when the individual concerned exercises his or her freedoms while holding an official position. Accordingly, the State may have a legitimate interest in limiting expressions made by its officials. After all, the receiver of said communication might not be able to distinguish easily between a statement made by the public official qua public official or qua private citizen. For the State, this distinction is important, as statements made in official functions are attributable to it. Also, a public employer, like every employer, will expect a certain level of loyalty from its employees. If an employee shows, through public statements, that he or she disagrees with his employer on issues of importance to the latter, and if there is even a risk that third parties might take the employee's view for the employer's official view, the employer-employee relationship is severely damaged. The same applies not only to private but also to public employers.

The question here is if, and if so, how far, the State may limit the freedom of speech of the members of the armed forces under the European Convention on Human Rights. We will first introduce the past dealings of the Court with applications brought forward by members of the armed forces. In particular, this article examines the case of Jokšas $v$. Lithuania, especially with regard to any special relationship of subordination. Furthermore, the freedom of expression as set out in Article 10 ECHR will be introduced and possible interferences will be presented during this analysis. Further on, this will be examined in the particular case of Jokšas.

\section{MEMBERS OF THE ARMED FORCES AND THE EUROPEAN CONVENTION ON HUMAN RIGHTS}

The European Court of Human Rights has dealt with applications by members of the armed forces on several occasions.

\subsection{VEREINIGUNG DEMOKRATISCHER SOLDATEN ÖSTERREICHS AND} GUBI V. AUSTRIA ${ }^{8}$

In 1994, the a private association of Austrian democratic soldiers together with one individual in the army complained to the Court with regard to an infringement of their right to freedom of expression. The focus within the Court's decision was not on the question of infringement itself, but on the parameters

\footnotetext{
8 Vereinigung demokratischer Soldaten Österreichs and Gubi v. Austria, European Court of Human Rights, Application No. 15153/89, Judgment of December 19, 1994, paragraph 32.
} 
under which such an infringement can be justifiable in accordance with Article 10 (2) ECHR.

The association published a critical magazine named Der Igel (the Hedgehog). ${ }^{9}$ Its distribution in barracks had been banned by the Austrian minister, which the first applicant saw as an unjustified infringement. The minister, however, explained his decision with his duty to prevent disorder in the armed forces. ${ }^{10}$ The second applicant tried to privately distribute the magazine in his barrack and was ordered to seize this by one of his superiors. ${ }^{11}$ In both issues, the Court determined that there had been infringements of the applicants' right, and those had not been justifiable with the prevention of disorder in the armed forces. ${ }^{12}$

\subsection{ENGEL ET AL. V. THE NETHERLANDS ${ }^{13}$}

The applicants in the case Engel et al. v. the Netherlands were all conscript soldiers serving in the Netherlands armed forces. ${ }^{14}$ With regard to Article 10 ECHR, the complaints brought forward by Mr. Dona and Mr. Schul are the relevant ones. Mr. Dona was editor of a journal called "Alarm", whose no. 8 had been provisionally prohibited distribution at the General Spoor barracks at Ermelo; this was, because the commanding officer found its contents to be inconsistent with military discipline. ${ }^{15}$ Subsequently, Mr. Dona was sentenced to three months' committal to a disciplinary unit for having taken part in the publication and distribution of a writing tending to undermine discipline. ${ }^{16} \mathrm{Mr}$. Schul was also an editor to the "Alarm" and the facts to his complaints are nearly identical to Mr. Dona's. Mr. Schul's punishment, however, initially amounted to four months, owing to the additional aggravating circumstance of his participation in the publication of an "Information Bulletin" for the new recruits; the distribution of which had been prohibited by reason of its negative content. ${ }^{17}$ The Court therein found an "unquestionable interference" with the applicants' rights under Article 10 ECHR, hence this interference was examined for a justification under paragraph $2 .{ }^{18}$ Again, the Court determined that the "prevention of disorder" also included enclosed social groups such as the military and that under the specific facts, this justified the punishment

\footnotetext{
9 Ibid., paragraph 7.

${ }^{10}$ Ibid., paragraph 8.

11 Ibid., paragraph 10.

12 Ibid., paragraph 40 and paragraph 49, last sentence.

13 Engel et al. $v$. the Netherlands, European Court of Human Rights, Application no. 5100/71; 5101/71; $5102 / 71 ; 5354 / 72 ; 5370 / 72$, Judgment of June $8,1976$.

14 Ibid., paragraph 12.

${ }^{15}$ Ibid., paragraph 43.

16 Ibid.

17 Ibid., paragraph 45.

18 Ibid., paragraph 95.
} 
of the applicants. ${ }^{19}$

\section{THE CASE OF JOKŠAS V. LITHUANIA BEFORE THE EUROPEAN COURT OF HUMAN RIGHTS 20}

In a recent case, the European Court of Human Rights had the opportunity to deal again with statements made by a servant of the State.

In the case of Jokšas $v$. Lithuania, the applicant lodged a complaint against the Republic of Lithuania with the European Court of Human Rights for violation of his rights pursuant to Article 6 of the Convention for the Protection of Human Rights and Fundamental Freedoms and Article 10 of the ECHR, taken alone or in conjunction with Article 14, on 6 June 2007. ${ }^{21}$ The applicant alleged that his right to freedom of expression had been violated because he had been discharged from the military on account of a public statement he had made (Article $10 \mathrm{ECHR}$ ). The applicant also complained that the domestic courts, which heard those complaints, were unfair, in breach of Article 6 paragraph 1 ECHR.

\subsection{FACTS OF THE CASE}

Mr. Alvydas Jokšas, a Lithuanian national born on June 19, 1956, had joined the Lithuanian army during the 1990s. ${ }^{22}$ Thus, he was in a close relationship of subordination with the State. The claimant approached a newspaper with an article critical of the new Army Disciplinary Statue. ${ }^{23}$ The article "War Without Constitutional Rights" was published on March 1, 2006, in Kauno Diena. ${ }^{24}$ Thereupon, the applicant's superiors initiated an internal investigation regarding his communication with journalists. ${ }^{25}$ On March, 13, 2006, the same newspaper published another article (entitled "Criticism of the Statute angers the Ministry [of Defence]") in which the applicant's criticism was cited. ${ }^{26}$ On June 19, 2006, the claimant's superiors signed an order dismissing him from his position on the grounds that he had reached retirement age. ${ }^{27}$ At this time, the applicant's professional service contract was still validly running. ${ }^{28}$ The applicant named as witnesses four servicemen that had already exceeded the age of retirement but

\footnotetext{
19 Ibid., paras. 98 and 101.

20 Jokšas v. Lithuania, European Court of Human Rights, Application No. 25330/07, Judgment of November 12, 2013.

${ }^{21}$ Ibid., paragraph 3.

${ }^{22}$ Ibid., paras. 5 et seq.

23 Ibid., paragraph 11.

24 Ibid.

25 Ibid., paragraph 12.

26 Ibid., paragraph 13.

27 Ibid., paragraph 16.

${ }^{28}$ Ibid., paragraph 7.
} 
were still in duty. ${ }^{29}$ The witnesses were never summoned before court. ${ }^{30}$ The applicant claims that he was not dismissed by reason of his age but rather as a consequence of his critical statements with the press ${ }^{31}$ and herein sees discrimination on the basis of opinion (Article 14 in conjunction with Article 10 ECHR). ${ }^{32}$

\subsection{DECISION}

In its decision, the court held that, while army officials' right to freedom of expression can be infringed on the grounds of protecting military discipline, the authorities cannot abuse this prerogative to punish any critical statement directed against that army as an institution. ${ }^{33}$ Since the applicant's dismissal cannot be directly attributed to the publication in the newspaper, ${ }^{34}$ the court finds no violation of Article $14 \mathrm{ECHR}$ (prohibition of discrimination). ${ }^{35}$ "Freedom of expression, as enshrined in Article 10, is subject to a number of exceptions", ${ }^{36}$ e.g. when the rights bearer is in a close relationship of subordination with a Contracting State to the ECHR. However, the infringement of the right must be especially justified. ${ }^{37}$ In the case at hand, the court held that there was no violation of Article $10 \mathrm{ECHR}{ }^{38}$

\section{SPECIAL RELATIONSHIP OF SUBORDINATION}

De facto all citizens find themselves in a relationship of subordination with their State, which can exercise a certain power over them. This can be explained with the fact that the inhabitants of a State have to abide by the laws created by said State, as well as the condition that the individuals' life in society is governed by the respective sovereignty. The closeness between the State authorities and the individual can be increased, however, until the latter faces a special relationship of subordination to the State, e.g. as a public official, government employee, prisoner or soldier.

\footnotetext{
${ }^{29}$ Ibid., paragraph 19.

${ }^{30}$ Ibid., paragraph 23.

${ }^{31}$ Ibid., paragraph 49.

32 Ibid., paragraph 3

33 Ibid., paras. 70 et seq.

${ }^{34}$ Ibid., paragraph 72.

35 Ibid., paragraph 74.

${ }^{36}$ Ibid., paragraph 69.

37 Ibid.; Vogt v. Germany, European Court of Human Rights, Application No. 17851/91, Judgment of September 26, 1995, paragraph 52.

38 Jokšas $v$. Lithuania, supra note 20 , paragraph 74.
} 


\subsection{DEFINITION}

This special relationship of subordination arises when the (subordinate) national enters a relationship with the power-exercising authority that can be described as closer than the normal condition. Such cases can be found where an institutional background can be detected, e.g. within civil service or the penal as well as the public school system. ${ }^{39}$

The special relationship between subject and state in the institutional context causes a shift in the State's duty to protect the citizen. ${ }^{40}$ To a certain extent, it lightens the State's obligation to safeguard its nationals against violations of the latter's fundamental and human rights - without denying that person's rights. ${ }^{41}$

\subsection{LEGAL STATUS OF INDIVIDUALS WITH A CLOSE RELATIONSHIP} OF SUBORDINATION

Those rights can be more easily affected when a special relationship of subordination is present. ${ }^{42}$ However, there has to be a legal basis for such a breach and the infringement needs to be justifiable. ${ }^{43}$ Therefore, when entering the discussed relationship, the individual is deemed to implicitly agree to let the State have an increased impact on his or her personal rights. ${ }^{44}$ While the State might infringe upon the civil servant's ${ }^{45}$ fundamental rights, it cannot do so without a sufficiently clear and specific legal provision. ${ }^{46}$ The civil servant, thus, has the right to have the infringement justified and can contest its rightfulness in court.

\footnotetext{
${ }^{39}$ No author named, "Besonderes Gewaltverhältnis/Sonderstatusverhältnis" //

http://www.lexexakt.de/glossar/besonderesgewaltverhaeltnis.php; Sebastian Graf von Kielmansegg, "Das Sonderstatusverhältnis," Juristische Arbeitsblätter 44 (2012): 881 // http://www.jaaktuell.de/root/img/pool/verschiedenes/aufsatz ja_12-2012.pdf.

40 Duty to protect, cf. Christian Starck, "State duties of protection and fundamental rights," Potchefstroom Electronic Law Journal 3 (2000): 1 //

http://dspace.nwu.ac.za/bitstream/handle/10394/1980/2000x1xstar_Articlepdf?sequence=3; Office of the High Commissioner for Human Rights, "What are Human Rights?," paragraph 1 //

http://www.ohchr.org/EN/Issues/Pages/WhatareHumanRights.aspx; Human Rights First, "Protecting Human Rights Defenders" // http://www.humanrightsfirst.org/our-work/human-rightsdefenders/protecting-human-rights-defenders.

${ }^{41}$ In 1972, the German Federal Constitutional Court has recognized that human rights are applicable also in such special relationships and that e.g. prisoners are holders of human rights despite their special relationship of subordination to public authorities has been recognized (BVerfGE 33, 1). After this judgment, the terminology was changed from "besonderes Gewaltverhältnis" ("special relationship of force") to "Sonderstatusverhältnis" ("relationship of special status"), thus indicating the shift in attitude towards those affected.

${ }^{42}$ Restrictive to this judgment, cf. BGE 98 Ib 301, Cons. 2a.

$43 \mathrm{Cf}$. for instance Article 36 of the Constitution of Switzerland; Vogt v. Germany, supra note 37, paragraph 53.

${ }^{44}$ This ties in with the general imcompatibility of freedom and power (see Norberto Bobbio, Das Zeitalter der Menschenrechte - Ist Toleranz durchsetzbar?, $1^{\text {st }}$ ed. (Berlin Verlag Klaus Wagenbach, 1999), p. 31): by moving to the side of power, the individual gives up some degree of freedom which, per se, would have to be directed against this power.

45 Here, the term "civil servant" is used for mere vividness, all other groups in an especially close relationship of subordination need to be taken into consideration.

${ }^{46}$ Sebastian Graf von Kielmansegg, supra note 39: 885.
} 
Moreover, individuals that find themselves in a close relationship of subordination with their State, e.g. civil servants, are held to respect other individuals' fundamental right when acting on behalf of the state. ${ }^{47}$

\section{FREEDOM OF EXPRESSION UNDER THE EUROPEAN CONVENTION ON HUMAN RIGHTS}

\subsection{PERSONAL SCOPE}

From the perspective of human rights law as a legal system, which aims at regulating the relationship between superior and inferior actors-i.e. the State, which is in a position of relative power, and individuals or groups of individuals, who, unlike the State, do not exercise power-the freedom of expression, as codified in Article $10 \mathrm{ECHR}$, is both an individual as well as a collective right. ${ }^{48}$

This general principle, indeed, the fundamental paradigm of human rights protecting the (powerless) individual against (powerful) authorities, might be questioned if public law entities could also claim human rights-including public officials, as far as their public function is concerned. In a number of cases the Strasbourg organs have recognized that public entities may indeed be able to claim some rights. ${ }^{49}$

What these cases have in common is that these (partially) public entities cannot claim human rights because of their public nature but in some cases they might have human rights despite otherwise having a public role.

Likewise, public officials or state employees cannot claim rights under the Convention in their official but only in their private function. For example, a government spokesperson is ordered to make a specific public announcement cannot invoke her right to free speech against the government for which she works. The case becomes somewhat less simple when the question is if a member of the armed forces who is deployed abroad for a tour of duty can invoke the right to respect for family life due to the separation from his family for the duration of the deployment. The difference here is the private interest of the claimant (although the soldier who is deployed abroad will find his rights limited by Article 8 Section 2 of the Convention). The central question in this context is whether public employees can utilize the Convention against their employer in the context of their

\footnotetext{
${ }^{47}$ Cf. for instance Part II - Rights and Duties of Civil Servants, Chapter II - Duties of Civil Servants of the Croatian Civil Servants Act from July 15, 2005.

48 Guerra Martins, supra note 5, p. 244.

${ }^{49}$ See, for example, Radio France and others v. France, European Court of Human Rights, Application No. 53984/00, Judgment of March 30, 2004, paras. 25 et seq.; and Islamic Republic of Iran Shipping Lines v. Turkey, European Court of Human Rights, Application No. 40998/98, Judgment of December 11, 2007, paras. 78 et seq., with further references.
} 
employment.

Assuming then that a public official may in principle be able to claim protection under Article 10 for statements which were not made in an official capacity, the next question that needs to be answered is if, and if yes, how, this right can be limited.

\subsection{INTERFERENCES}

While the wording of Article 10 paragraph $1 \mathrm{ECHR}$ ("without interference") gives the reader the impression of an irrestrictable right ${ }^{50}$, paragraph 2 shows that restrictions are indeed possible. ${ }^{51}$ These permitted interferences can be both reactive as well as preventive in nature. ${ }^{52}$ With regard to potential limitations of the freedom of expression of public officials or persons who are working for public authorities, the jurisprudence of the Convention organs appears to be lacking a clear direction. ${ }^{53}$ It is recognized that there is an interference with the right of an employee (but not of an appointed, rather than employed, public official) ${ }^{54}$ of a public entity when he or she is dismissed because of a statement he or she had made. ${ }^{55}$ Article 10 paragraph 1 of the Convention can also be infringed upon if a person is not appointed to a public office because of an earlier use of this freedom. ${ }^{56}$

Interference with the freedom of expression, which is contained in Article 10 paragraph 1 , is only permitted under the conditions set by Article 10 paragraph 2 ECHR. ${ }^{57}$ Paragraph 2 of Article 10 almost-but only almost-mirrors the respective second paragraphs of Articles 8, 9 and $11 .{ }^{58}$ The last sentence of Article 11 (2) ECHR allows for special restrictions of the freedoms of assembly and association ${ }^{59}$ for members of the armed forces. ${ }^{60}$ Such a rule is not included in Article 10 ECHR. Therefore, a solution will have to be found in accordance with both Article $10 \mathrm{ECHR}$ and general rules.

The ECHR requires the state to base the infringement on domestic legislation.

${ }^{50}$ Christoph Grabenwarter, supra note 7, p. 258.

${ }^{51}$ Ibid.

52 Ibid.

53 Ibid., p. 259.

54 Glasenapp v. Germany, European Court of Human Rights, Application No. 9228/80, Judgment of August 28, 1986, paragraph 49; Kosiek v. Germany, European Court of Human Rights, Application No. 9704/82, Judgment of August 28, 1986, paragraph 35; but see also the opposing view of Christoph Grabenwarter, supra note 7, p. 260, with further references, ibid., fn. 68

${ }_{55}$ Christoph Grabenwarter, supra note 7, p. 260; Vogt v. Germany, supra note 37, paragraph 44.

56 Wille v. Liechtenstein, European Court of Human Rights, Application No. 28396/95, Judgment of October 28, 1999, paras. 49 et seq.

${ }^{57}$ Christoph Grabenwarter, supra note 7, p. 260.

${ }^{58}$ Ibid.

${ }^{59}$ Article 11 of ECHR, paragraph 2, first sentence.

${ }^{60}$ Article 11 of ECHR, paragraph 2, last sentence. See also Christoph Grabenwarter, supra note 7, p. 269. 
With regard to public employees, this will require, for example, disciplinary rules for this category of employees-including enforcement regulations, which allow, for example, for the termination of the employment. In particular when it comes to public employees, legally foreseen restrictions of the freedom of expression might easily be abused to stifle dissent, political or otherwise. In fact, many forms or contents of expressions might be considered 'dissent', be it any form of religiosity in a secular society or political opposition. In order to better protect the freedom of expression, however, paragraph 2 of Article 10 ECHR limits the restrictability to a number of goals the state may pursue with such a restriction of the freedom of expression. The slight differences between Article 10 paragraph 2 ECHR and the respective paragraphs 2 of Articles 8, 9 and 11 ECHR indicate that paragraph 2 of Article 10 ECHR was designed specifically with the freedoms of paragraph 1 in mind. ${ }^{61}$ Among these legitimate goals are the protection of national security as well as of order. The latter not only refers to public order but also to order within specific aspects of society ${ }^{62}$-such as the armed forces. ${ }^{63}$

One argument in favor of the possibility to restrict the freedom of speech of public officials and soldiers in the interest of democracy ${ }^{64}$ can be found in the reference to "duties and responsibilities" in Article 10 paragraph 2 ECHR. ${ }^{65}$ On this basis, States are said to have a margin of appreciation in deciding how to limit the freedom of expression of soldiers and public officials for the purpose of ensuring that the constitution is upheld by the soldier or official ${ }^{66}$ as well as for the purpose of ensuring their neutrality. ${ }^{67}$

Politicians ${ }^{68}$ enjoy a very far-ranging protection of their freedom of speech $^{69}$ as limitations have to comply with an even more precise proportionality test ${ }^{70}$ or at least a restricted margin of appreciation. ${ }^{71}$ This also applies to politicians who hold a public office, but only in so far as they act in their private capacities. As soon as they act in their public functions, they cannot claim rights against the State they

\footnotetext{
${ }^{61}$ Christoph Grabenwarter, supra note 7, p. 262.

62 Vereinigung demokratischer Soldaten Österreichs and Gubi v. Austria, supra note 8, paragraph 32.

63 Ibid.

${ }^{64}$ Christoph Grabenwarter, supra note 7, p. 269.

65 Ibid., p. 270

66 See Vogt v. Germany, supra note 37, paragraph 51.

67 Christoph Grabenwarter, supra note 7, p. 270.

68 On political speech in general see Lingens $v$. Austria, European Court of Human Rights, Application No. 9815/82, Judgment of July 8, 1996; Mark W. Janis, Richard S. Kay, and Anthony W. Bradley, European Human Rights Law - Text and Materials, $3^{\text {rd }}$ ed. (Oxford: Oxford University Press, 2008), pp. 256 et seq.

${ }^{69}$ On political speech see in more detail Philip Leach, Taking a Case to the European Court of Human Rights, $2^{\text {nd }}$ ed. (Oxford: Oxford University Press, 2005), pp. 322 et seq.

${ }^{70}$ Christoph Grabenwarter, supra note 7, p. 265

71 Philip Leach, supra note 69, p. 321. For a critical view on the doctrine of the margin of appreciation see Jeffrey A. Brauch, "The Margin of Appreciation and the Jurisprudence of the European Court of Human Rights: Threat to the Rule of Law," Columbia Journal of European Law 11 (2005) // http://papers.ssrn.com/sol3/papers.cfm?abstract_id=2094565. But see also Howard C. Yourow, The Margin of Appreciation Doctrine in the Dynamics of European Human Rights Jurisprudence, $1^{\text {st }}$ ed. (Dordrecht: Kluwer Academic Publishers, 1996).
} 
represent. In fact, elected representatives enjoy a higher degree of protection than others. ${ }^{72}$

The same cannot necessarily be said for members of the armed forces. The Convention organs have had several occasions to rule on cases related to the exercise of the freedom of expression by members of the armed forces ${ }^{73}$ and have continuously permitted the state to restrict soldiers' freedom of expression.

\subsection{DUTIES AND RESPONSIBILITIES IN THE EXERCISE OF THE FREEDOM OF EXPRESSION}

The freedom of expression is to be exercised in accordance with existing duties, ${ }^{74}$ which also applies to the obligations members of the armed forces have towards the state they serve. ${ }^{75}$

Furthermore, it appears questionable whether the rather general reference to "duties and responsibilities" in paragraph 2 of Article 10 of the Convention has a normative value of its own, which would go beyond the mere prohibition of the abuse of the right under paragraph 1 . The fact that Article 17 ECHR explicitly aims at preventing abuses of the rights that are codified in the Convention does not diminish the possibility that a specific norm could have more specific rules against such abuses. In fact, the wording of Article 17 ECHR, which refers to preventing activities that are "aimed at the destruction" of rights which are codified in the Convention, shows that the latter norm only applies to cases in which intentional measures are taken to destroy said rights and freedoms. A mere reference to "duties and responsibilities" rights ought to be exercised. This covers also actions (and omissions), which are not aimed at anything, let alone the destruction of rights. In the case of the freedom of expression, this means that there seem to be limits to the exercise of the right which are not imposed by the State under Article 10 paragraph 2 but which are only recognized in Article 10 paragraph 2 as being inherent in the exercise of the right as such. The freedom of expression thereby differs fundamentally from other human rights, since, though its material scope is very wide, including even the transmission of known untrue statements, the exercise of this right is inherently limited. This limitation also leads to behaviors falling outside the scope of the norm, which do not reach the level of Article 17. Therefore, the reference to "duties and responsibilities" in the exercise of the rights under Article

72 Christoph Grabenwarter, supra note 7, pp. 265 et seq.; Castells v. Spain, European Court of Human Rights, Application No. 11798/85, Judgment of April 23, 1992, paragraph 42.

${ }^{73}$ Cf. supra 1.

74 Article 10 (2) of ECHR.

${ }^{75}$ Christoph Grabenwarter, supra note 7, pp. 269 et seq.

${ }^{76}$ Article 10 of ECHR, paragraph 2. 
10 paragraph 1 has a specific normative value. However, it appears difficult for the State to enforce this particular limitation since doing so would open the door to restrictions of the right outside the mechanism of paragraph 2. After all, the State might be tempted to establish in domestic law duties of the right holder, which can only meaningfully apply to the exercise of the right-but such laws would not have to pass the test of paragraph 2 since it would not amount to a limitation but a definition of the scope of paragraph 1.

Among the responsibilities and duties the Court has found in relation to the exercise of the freedom of expression is the duty not to intentionally behave in an offensive manner towards objects that have a high religious value for others. ${ }^{77}$ This indicates that the duties and responsibilities mentioned in Article 10 paragraph 2 are not be established by States but are inherent in the exercise of the right under paragraph 1 of the same norm. Being inherent in the exercise of a right under the Convention, such duties and restrictions exist independently from national law. But the European Court of Human Rights is not the only body which is to interpret the Convention. To apply the Convention domestically, States have to interpret the Convention. This opens the door for States to find duties and responsibilities inherent in the freedom of expression. Different approaches to the freedom of expression can lead to different interpretations. A domestically codified right to free speech may be more narrow than the right under Article $10 \mathrm{ECHR}$ and States might aim at a coherent interpretation of their domestic free speech-rule and Article 10 ECHR. For example, States, which have ratified the Convention, might exclude from their national free speech clauses the right to make statements, which are known to be untrue. ${ }^{78}$ By interpreting Article 10 ECHR in the same way, the State would de facto regulate the scope of the norm. Instead, Article 10 has to be interpreted on its own, regardless of national laws. This does not mean that States cannot aim for some level of concordance.

In relation to public officials these "duties and responsibilities" are of particular relevance ${ }^{79}$ and the goal of "ensuring the functioning of the civil service" 80 is to be reached by aiming for "a fair balance between the rights of the individual and the interests of the state ${ }^{\prime \prime 1}$. This, however, does not only refer to the exercise of this right by public officials but also to the protection of public officials against the exercise of this right by others. ${ }^{82}$

\footnotetext{
77 Philip Leach, supra note 69, p. 321; Wingrove v. the United Kingdom, European Court of Human Rights, Application No. 17419/90, Judgment of November 25, 1996, paragraph 52.

78 See Christoph Grabenwarter, supra note 7, p. 254, there fn. 9.

79 Philip Leach, supra note 69, p. 325, with further references.

80 Ibid.

81 Ibid.

${ }^{82}$ Ibid., p. 325 et seq.
} 


\subsection{MARGIN OF APPRECIATION}

Based on the implied limitation of the freedom of expression in the form of obligations incumbent on rights holders, States have a margin of appreciation concerning the exercise of the freedom of expression. Whenever the State aims to regulate behavior of a rights holder by redefining the scope of a norm, particular attention needs to be paid to the danger that the Convention is circumvented. However, States do have some margin of appreciation in the application of the norm. Given that in the context of Article 10 restrictions which are based on paragraph 2 "must be narrowly interpreted and the need for restriction must be convincingly established" ${ }^{\prime 83}$, the State will also have to show restraint when invoking the margin of appreciation doctrine. However, it is accepted that the specific national context-both political as well as historic-can play an important role in deciding whether the state has stayed within the limits of the margin of appreciation. ${ }^{84}$

How far the margin of appreciation can reach in cases concerning Article 10 ECHR is not defined clearly but rather has to be decided not necessarily anew for every individual case but by taking into account the specific context. This lack of clarity $^{85}$ does meet opposition ${ }^{86}$.

The European Court of Human Rights, however, has not issued definitions of the relevant notions of national security and prevention of disorder by way of autonomous concepts. This lack of legal definition leads to the presumption that Member States have a margin of appreciation when applying them.

\section{FREEDOM OF EXPRESSION IN JOKŠAS}

In the case at hand, the applicant complains about a violation of his right to free expression as set forth in Article 10 of the ECHR. One also needs to take into consideration that the applicant was acting as a member of the armed forces in the events leading up to the legal issue of the case. The claimant had entered a special relationship of subordination, which gave the state authorities a certain right to infringe his rights when it was justifiable with a special interest of the State. In Jokšas $v$. Lithuania, the government considered the "interests of national security" ${ }^{187}$ and "prevention of disorder"88 to be legitimate goals which may be pursued by the

\footnotetext{
83 Ibid., p. 321, with further reference.

${ }^{84}$ Christoph Grabenwarter, supra note 7, p. 270.

85 Philip Leach, supra note 69, p. 321.

86 See ibid., fn. 935 for further references.

87 Jokšas v. Lithuania, supra note 20, paragraph 65

88 Ibid.
} 
means of an infringement of rights for the official. ${ }^{89}$ In doing so, the Court followed the precedents in Engel $v$. the Netherlands and Vereinigung demokratischer Soldaten Österreichs and Gubi v. Austria. There, the Court pronounced an infringement unjustified "if it was not "prescribed by law", if it did not pursue one of more legitimate aims referred to in paragraph 2 of that Article (Article 10-2) or if it was not "necessary in a democratic society" in order to attain such aims". ${ }^{90}$ In Vereinigung demokratischer Soldaten Österreichs and Gubi v. Austria, disorder was to be prevented in the armed forces ${ }^{91}$. Meanwhile in Engel $v$. the Netherlands, the Court sets that "disorder" must not only concern a greater public order (ordre public), but can only suggest an order "within the confines of a specific social group", thus designating the prevention of disorder within the armed forces as a legitimate aim. ${ }^{92}$

Jokšas presents a classical case of an infringement of a human right, which can, however, be justified and declared lawful by taking into account the plaintiff's special legal relationship with his State. Following its precedent in Harabin $v$. Slovakia ${ }^{93}$, the Court considered the infringement of the right to freedom of expression to have not been disproportionate but to be justifiable. ${ }^{94}$

\section{CONCLUSION}

The Court's judgment in the case against Lithuania follows the aforementioned cases against the Netherlands and Austria. The Court has confirmed that members of the armed forces continue not merely to be held to a stricter standard when it comes to the way in which they can exercise their freedom of expression. Rather, states have a right to limit the exercise of the freedom of expression of members of the armed forces in accordance with the general rules under Article 10 ECHR for specific purposes. While the definition of said purposes could be considered to be insufficiently clear under many national legal systems, the European Convention on Human Rights gives states a margin of appreciation regarding the implementation of the Convention and the ways in which states comply with it. This means that-within the framework provided by the Convention as interpreted by the Court-the states have the freedom to decide how to interpret

\footnotetext{
${ }^{89}$ Ibid.

90 Vereinigung demokratischer Soldaten Österreichs and Gubi v. Austria, supra note 8, paragraph 28.

${ }^{91}$ Ibid., paragraph 32.

92 Engel et al. v. the Netherlands, supra note 13, paragraph 98. See also Christoph Grabenwerter, European Convention on Human Rights, Commentary (Munich: C.H. Beck, 2013), p. 264: "The prevention of public disorder encompasses the public order as well as the order of a specific sector of society or an institution such as the army or a prison."

93 Compare to the case of Harabin $v$. Slovakia, European Court of Human Rights, Application no. 58688/11, Judgment of November 20, 2012, paragraph 149.

94 Jokšas v. Lithuania, supra note 20, paragraph 74 .
} 
terms such as "national security". The Court could also choose to prevent abuses of this margin of appreciation by providing its own definitions in the form of autonomous concepts. In the case of such sensitive issues as national security, the Court is unlikely to do so.

Unlike in earlier cases, in particular Engel et al. v. the Netherlands in 1976 to and Vereinigung Demokratischer Soldaten Österreichs and Gubi v. Austria in 1994, the Court now put the emphasis on paragraph 2 of Article $10 \mathrm{ECHR}$ rather than on implied limitations. While the Court will have to take into account the parties submissions, the decision to step away from implied limitations and to focus on paragraph 2 strengthens the protection of the freedom of expression by choosing a solution which is dogmatically sound while reducing the risk of abuses of the States' possibility to rely on implied limitations.

Initially it was asked how far members of the armed forces can rely on Article 10 ECHR in order to express an opinion, the expression of which the State seeks to limit. Following the court's reasoning, these rights can be infringed upon (while not violated), if the necessary conditions as presented above are fulfilled. In cases in which individuals in their role as officials of the State exercise their right under Article $10 \mathrm{ECHR}$, the competing interests of State and official are thus balanced. The decision in Jokšas does not mean that the notion of implied limitations has been completely abandoned as far as members of the armed forces.

\section{BIBLIOGRAPHY}

1. Beetham, David. "Freedom as the Foundation." Journal of Democracy 15 (2004): 61-75.

2. Bobbio, Norberto. Das Zeitalter der Menschenrechte - Ist Toleranz durchsetzbar? $1^{\text {st }}$ ed. Berlin: Verlag Klaus Wagenbach, 1999.

3. Brauch, Jeffrey A. "The Margin of Appreciation and the Jurisprudence of the European Court of Human Rights: Threat to the Rule of Law." Columbia Journal of European Law 11 (2005) //

http://papers.ssrn.com/sol3/papers.cfm?abstract_id=2094565.

4. Casadevall, Josep, Egbert Myjer, Michael O’Boyle, and Anna Austin. Freedom of Expression: Essays in Honor of Nicolas Bratza, President of the European Court of Human Rights. $1^{\text {st }}$ ed. Strasbourg, Council of Europe, 2012.

5. Grabenwarter, Christoph. Europäische Menschenrechtskonvention. $3^{\text {rd }}$ ed. Munich: C.H. Beck, 2008.

6. Grabenwarter, Christoph. European Convention on Human Rights, Commentary. Munich: C.H. Beck, 2013. 
7. Guerra Martins, Ana Maria. Direito Internacional dos Direitos Humanos. $1^{\text {st }}$ ed. Coimbra: Almedina, 2013.

8. Human Rights First. "Protecting Human Rights Defenders" // http://www.humanrightsfirst.org/our-work/human-rightsdefenders/protecting-human-rights-defenders.

9. Janis, Mark W., Richard S. Kay, and Anthony W. Bradley. European Human Rights Law - Text and Materials. $3^{\text {rd }}$ ed. Oxford: Oxford University Press, 2008.

10. Leach, Philip. Taking a Case to the European Court of Human Rights. $2^{\text {nd }}$ ed. Oxford: Oxford University Press, 2005.

11. Letsas, George. A Theory of Interpretation of the European Convention on Human Rights. $1^{\text {st }}$ ed. Oxford: Oxford University Press, 2007.

12. Menke, Christoph, and Arnd Pollmann. Philosophie der Menschenrechte - zur Einführung. $1^{\text {st }}$ ed. Hamburg: Junius Verlag, 2007.

13. No author named. "Besonderes Gewaltverhältnis/Sonderstatusverhältnis" // http://www.lexexakt.de/glossar/besonderesgewaltverhaeltnis.php.

14. Office of the High Commissioner for Human Rights. "What are Human Rights?" // http://www.ohchr.org/EN/Issues/Pages/WhatareHumanRights.aspx.

15. Reid, Karen. A Practitioner's Guide to the European Convention on Human Rights. $3^{\text {rd }}$ ed. London: Thomson \& Sweet Maxwell, 2007.

16. Starck, Christian. "State duties of protection and fundamental rights." Potchefstroom Electronic Law Journal 3 (2000): 1-91 // http://dspace.nwu.ac.za/bitstream/handle/10394/1980/2000x1xstar_Articlep df? sequence $=3$.

17. Von Kielmansegg, Sebastian Graf. "Das Sonderstatusverhältnis." Juristische Arbeitsblätter 44 (2012): 881-887 // http://www.ja-aktuell.de/root/img/pool/verschiedenes/aufsatz_ja_122012.pdf.

18. Yourow, Howard C. The Margin of Appreciation Doctrine in the Dynamics of European Human Rights Jurisprudence. $1^{\text {st }}$ ed. Dordrecht: Kluwer Academic Publishers, 1996. 